
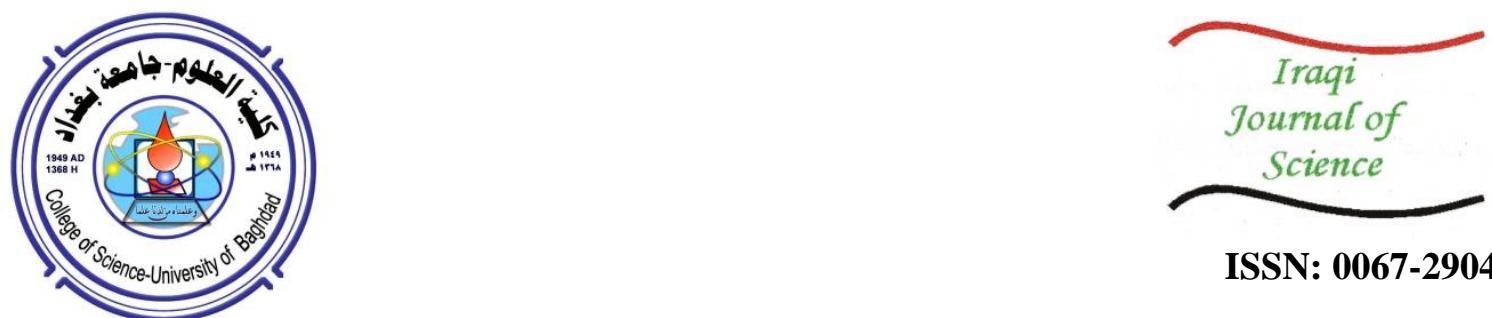

ISSN: 0067-2904

\title{
Predicting the Depositional Environments of Mishrif Formation from Seismic Isopach Map in the Dujaila Oil Field, Southeast- Iraq
}

\author{
${ }^{*}$ Ahmed Muslim Khawaja ${ }^{1}$, Jassim Muhammad Thabit ${ }^{2}$ \\ ${ }^{1}$ Department of Applied Geology, College of Science, University of Babylon, Iraq \\ ${ }^{2}$ Department of Geology, College of Science, University of Baghdad, Baghdad, Iraq
}

Received: 19/8/2020

Accepted: 29/9/2020

\begin{abstract}
In this paper, we attempt to predict the depositional environments with associated lithofacies of the main reservoir of the late Cretaceous Mishrif carbonate Formation, depending on the analysis of the created seismic isopach map by integrating seismic and well data. The isopach map was created from a 3D-seismic reflection survey carried out at the Dujaila oil field in southeastern Iraq, which is of an area of 602.26 $\mathrm{Km} 2$, and integrated with the data of the two explored wells. Based on the interpretation of the seismic isopach map, the diagram of the 3D-depositional environment model of Mishrif Formation was constructed. It showed three distinguished depositional environments, which were graduated from a back reef lithofacies of a shallow open marine (shelf) environment in the west and NW, to a shoal environment of isolated Rudist reefal buildup in the middle, and a fore reef lithofacies of the deep open marine basin environment in the SE of the field. A 3Dinstantaneous frequency model was generated to verify the capability of the seismic isopach map of predicting the depositional environments, which in turn showed that the low frequency was restricted in the region of the high thickness of Rudist reefal buildups (porous reservoir facies) in the vicinity of the productive well Dujaila-1.
\end{abstract}

Keywords: 3D-Seismic, Isopach map, Depositional environments, Instantaneous frequency attribute, Mishrif Formation, Dujaila oil field.

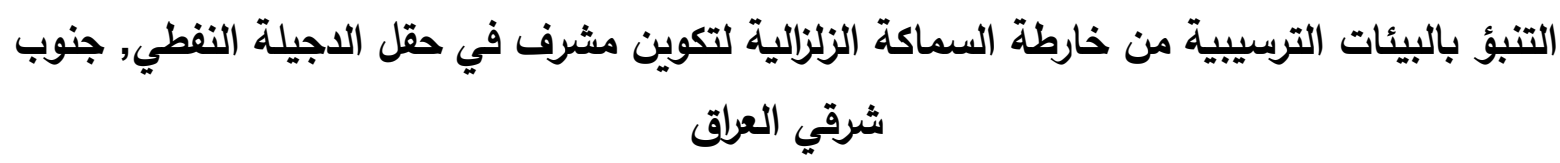

$$
\begin{aligned}
& \text { "احمد مسلم خواجة" , جاسم طحمد ثابت } 2
\end{aligned}
$$

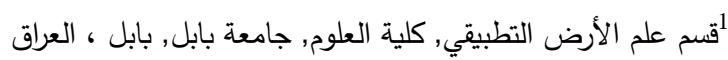

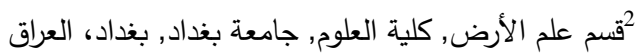

$$
\begin{aligned}
& \text { الخلاصة } \\
& \text { هذا البحث، محاوله للتبؤ بالبيئات الترسيبية والسحنات الصخرية لتكوين مشرف الكلسي (الكريتاسي }
\end{aligned}
$$

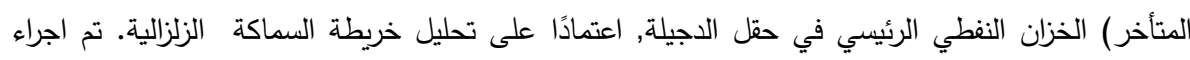

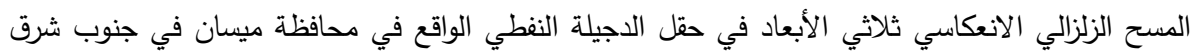

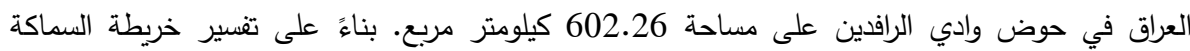

"Email: sci.ahmed.moslem@uobabylon.edu.iq 


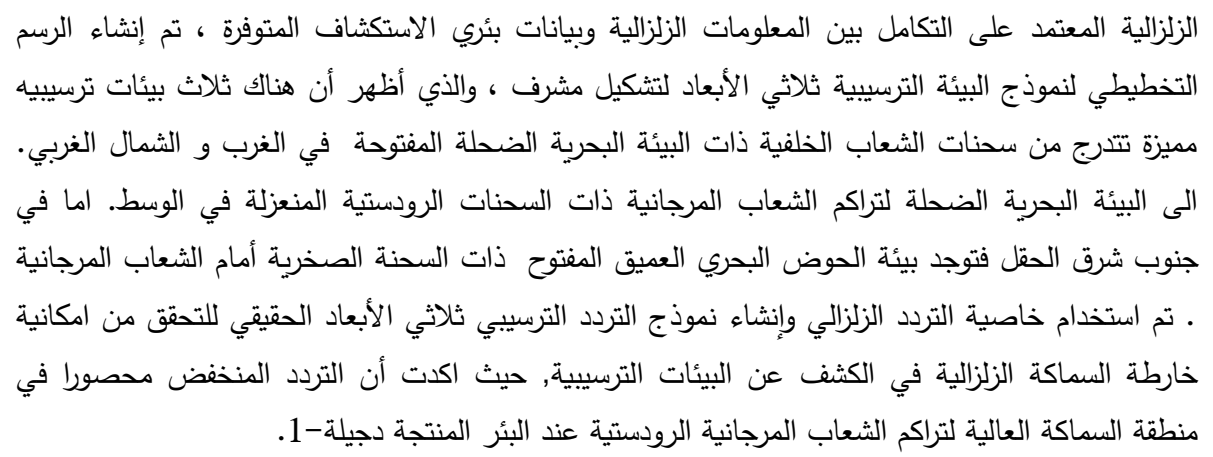

\section{Introduction}

Modern three-dimensional (3D) seismic data assists not only in delineating reservoir geometry but also in predicting petrophysical properties (thickness, porosity, and lithology) with variations away from those of the well control [1]. The geologic model derived from combining the 3D seismic survey with available well data provides a degree of detail about the depositional environments of the producing reservoir that cannot be obtained from well data alone [2]. This research is interested in predicting the thickness and delineation of the depositional facies environments of Mishrif Formation (Cenomanian-Early Turonian), which is the main reservoir in Dujaila oil field, depending on the integration of the 3D post-stack time migrated seismic data and available data of two wells. The Dujaila oil field is one of the promising fields in the Mesopotamian basin that was discovered before 1960 and has not been exploited to this day. A 3D-seismic reflection survey was carried out in 2010 by the second crew of the Iraqi Oil Exploration Company [3], which is also responsible for processing the seismic data. Two exploration wells are available in the Dujaila field. The first well is Dujaila-1 (Du-1) that was drilled in 1960 and produced oil from Mishrif Formation. While the second well is Dujaila-2 (Du-2) which was drilled in the1981 and is a dry well [4]. This study aims to estimate the depositional environments and associated lithofacies of the carbonate reservoir of Mishrif Formation from the seismic isopach map.

\section{Location of the Study Area}

Dujaila oil field is located in the southeastern part of Iraq in Maysan Governorate, about $50 \mathrm{Km}$ to the NW of Amara city and about $250 \mathrm{Km}$ to the south of the capital Baghdad, as seen in Figure-1. The study area is generally a flat terrain covered by Quaternary Period deposits, which is characterized by prevailing floodplain sediments and swamp deposits, in addition to the aeolian sediments spreading in the western part [5]. Structurally, Dujaila oil field lies in the Mesopotamian foredeep basin of the outer platform of the Arabian plate [6], as illustrated in Figure-1.

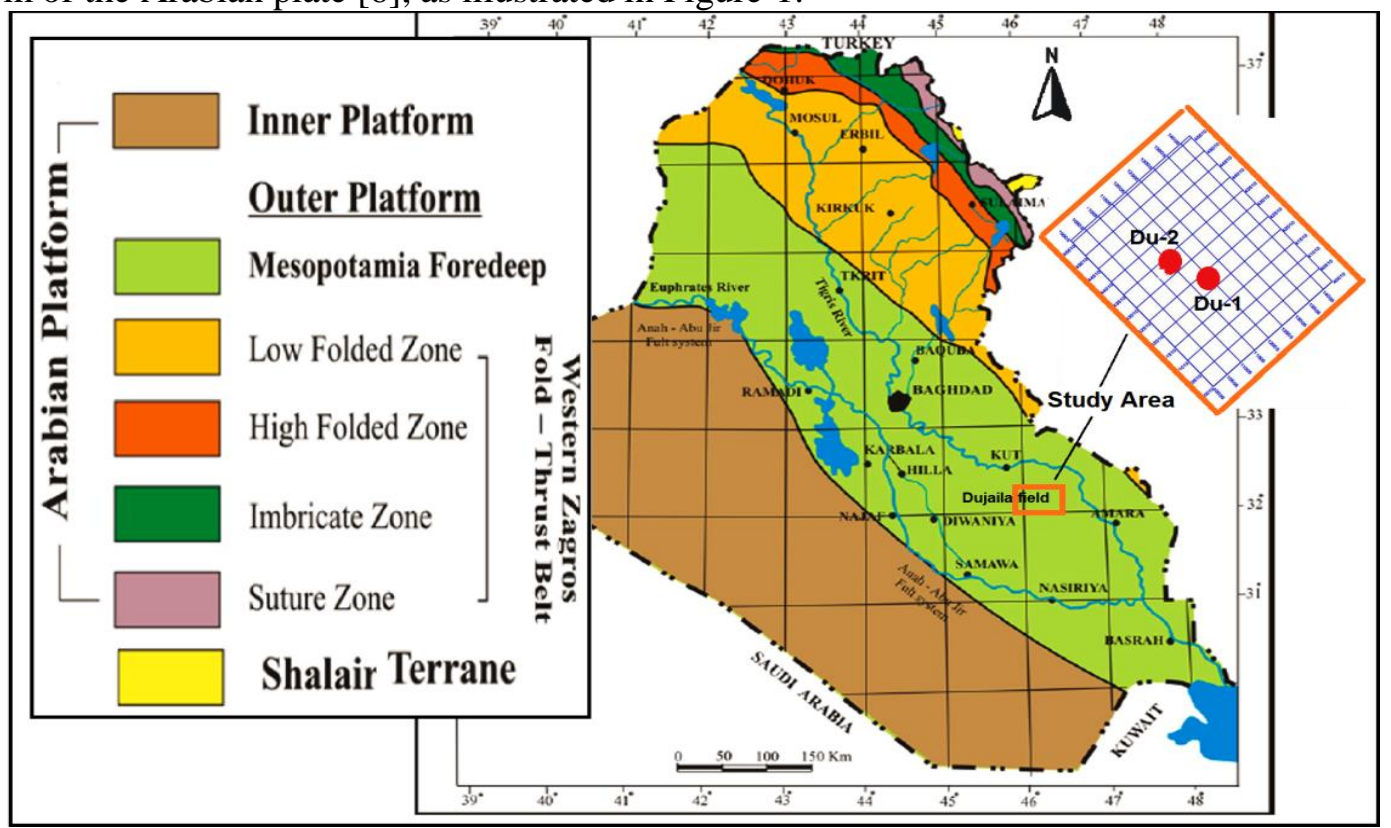

Figure1- The location of the study area on the structural map of Iraq, after [6] 


\section{Time Maps of Mishrif Formation}

The structural interpretation of the 3D seismic reflection data is directly dependent on the time maps of the reflection horizons, which resulted from identifying and picking the seismic reflectors in the two-way vertical time (TWT) unit that was calibrated and correlated with the well data through the seismic-well-tie synthetic seismogram [7], as displayed in Figure-2. Contour time maps for the top and bottom surfaces of Mishrif Formation were drawn with contour interval $5 \mathrm{~ms}$ to show the geometry of the captured reflection horizons, as seen in Figures-(3 and 4), respectively. Then, the 3D-seismic reflection horizons model for the identified and picked reflection horizons (four main strata units) of Mishrif Formation, on the entire seismic cube of Dujaila field, was generated to show the general topography of Mishrif Formation, as shown in Figure-5.

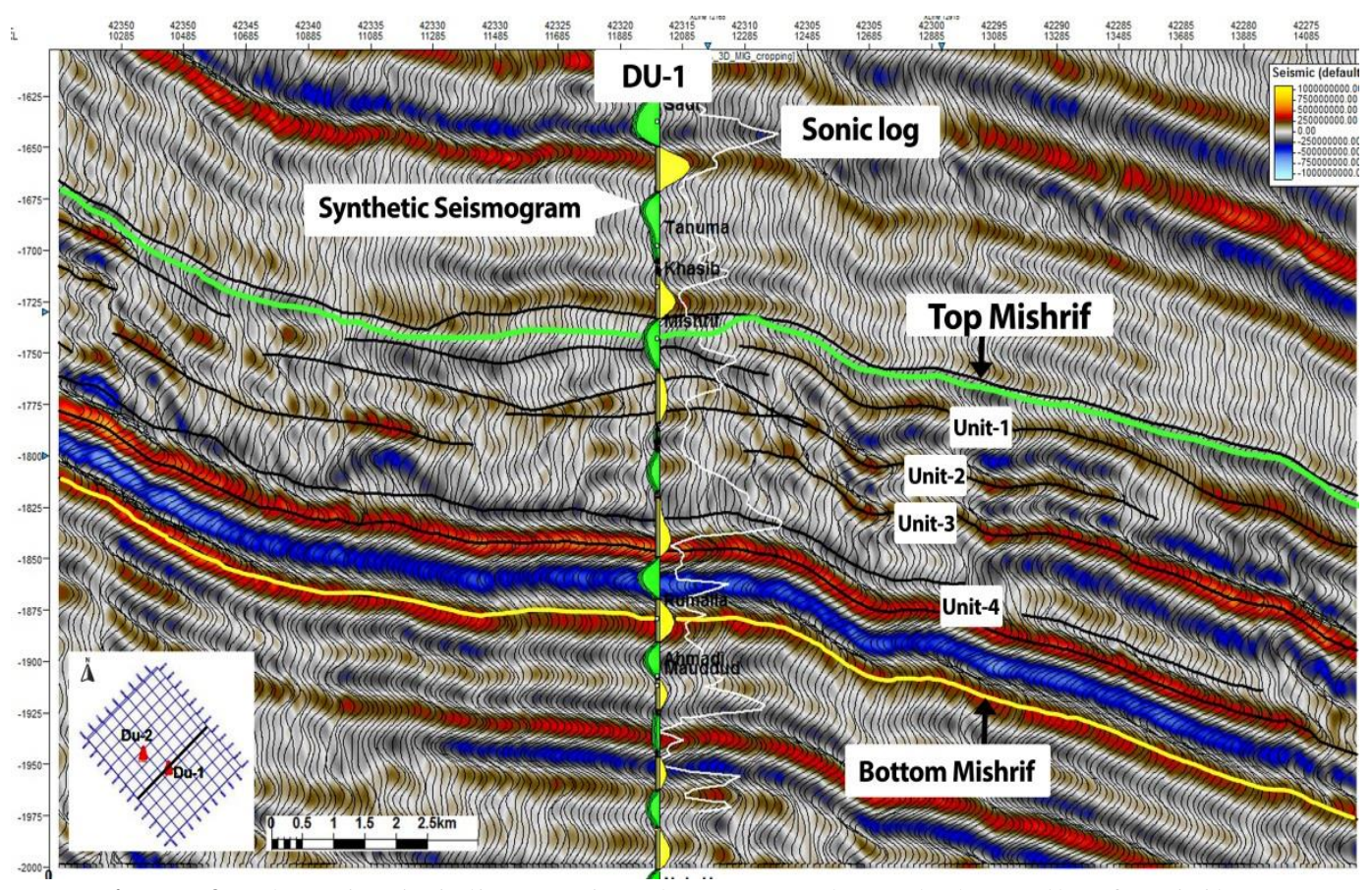

Figure 2- The seismic inline section that passes through the wells of Dujaila-1.

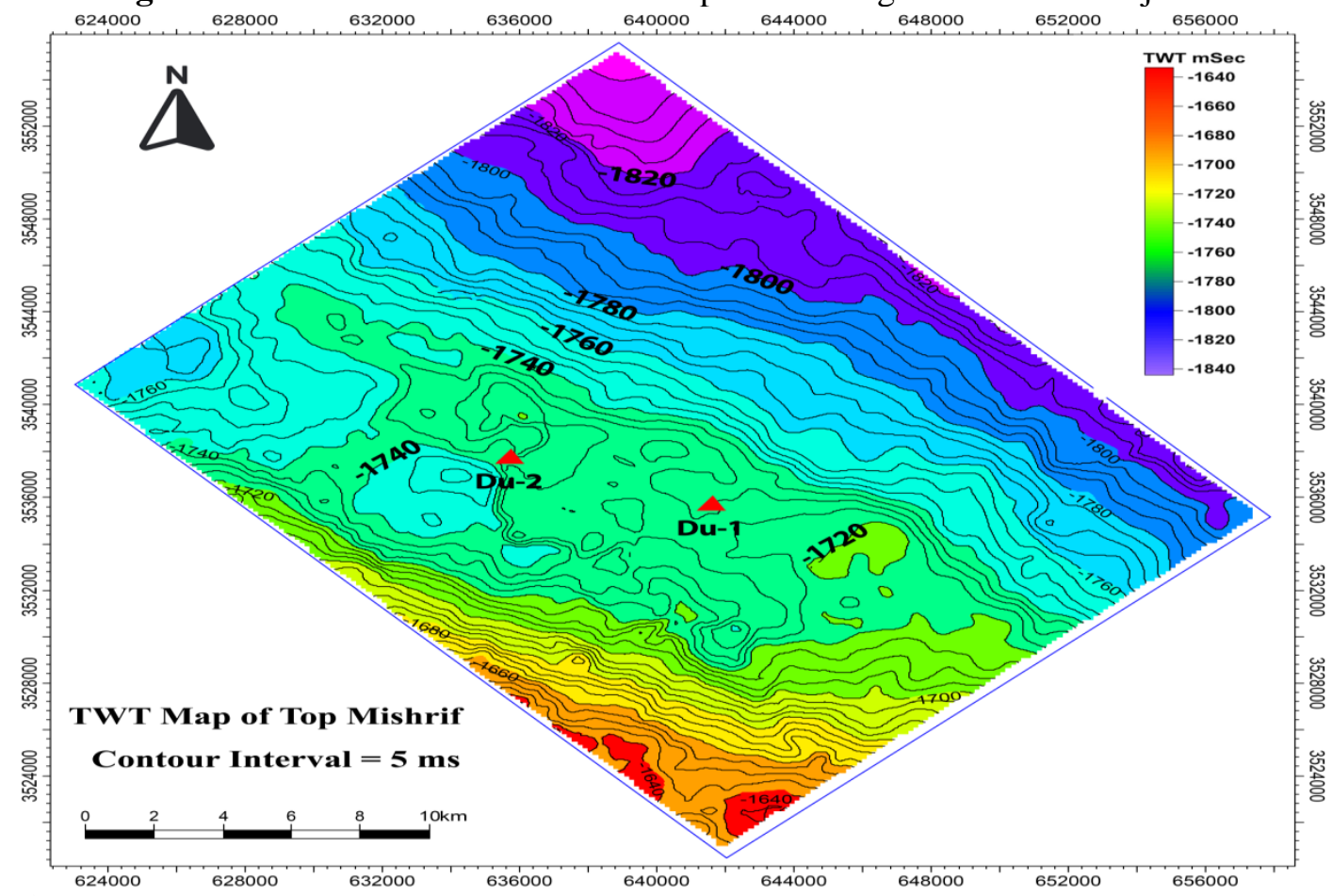

Figure 3- The TWT map of the top of Mishrif Formation with contour interval of $5 \mathrm{~ms}$. 


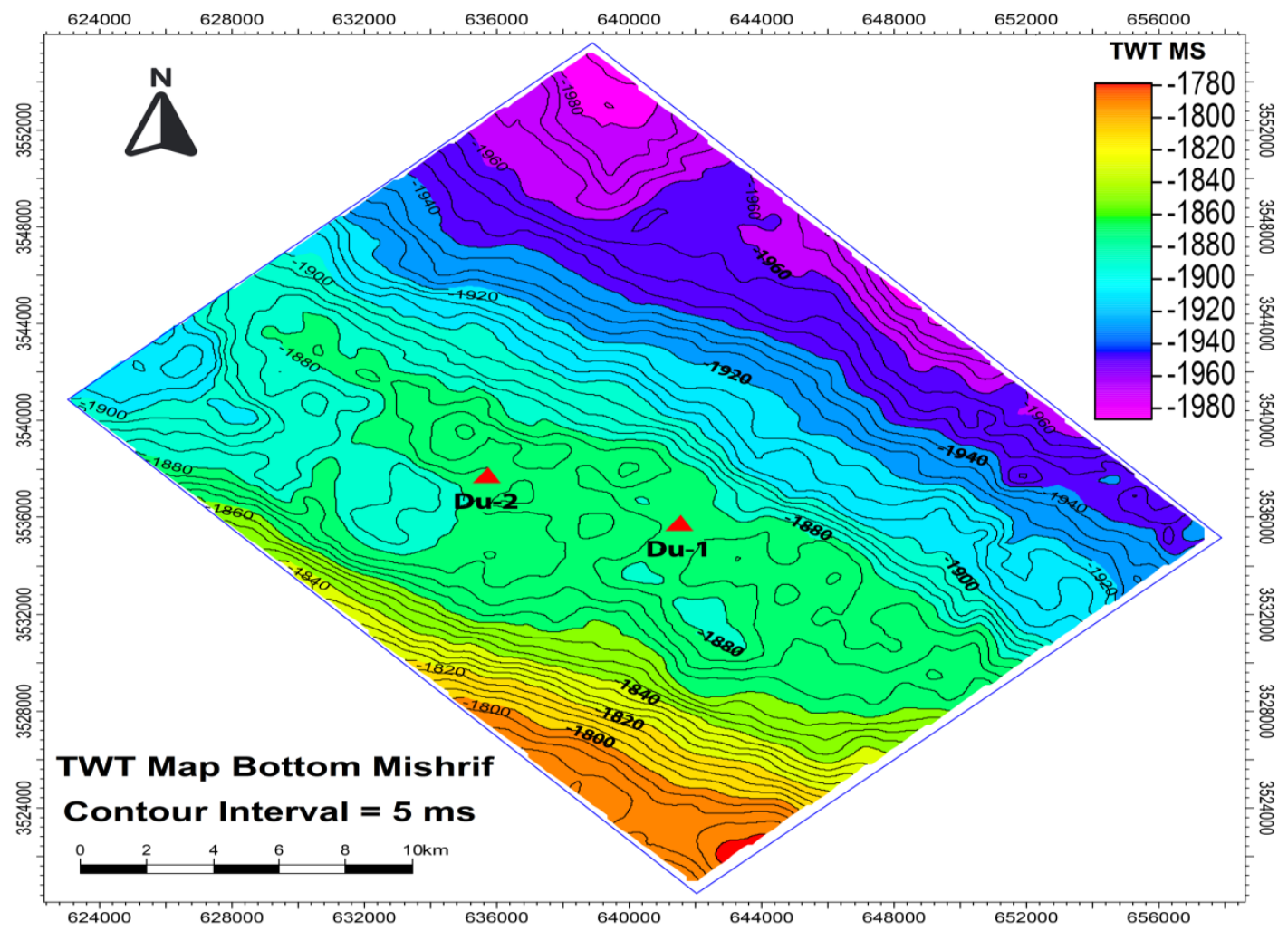

Figure 4- The TWT map of the bottom of Mishrif Formation with contour interval of $5 \mathrm{~ms}$.

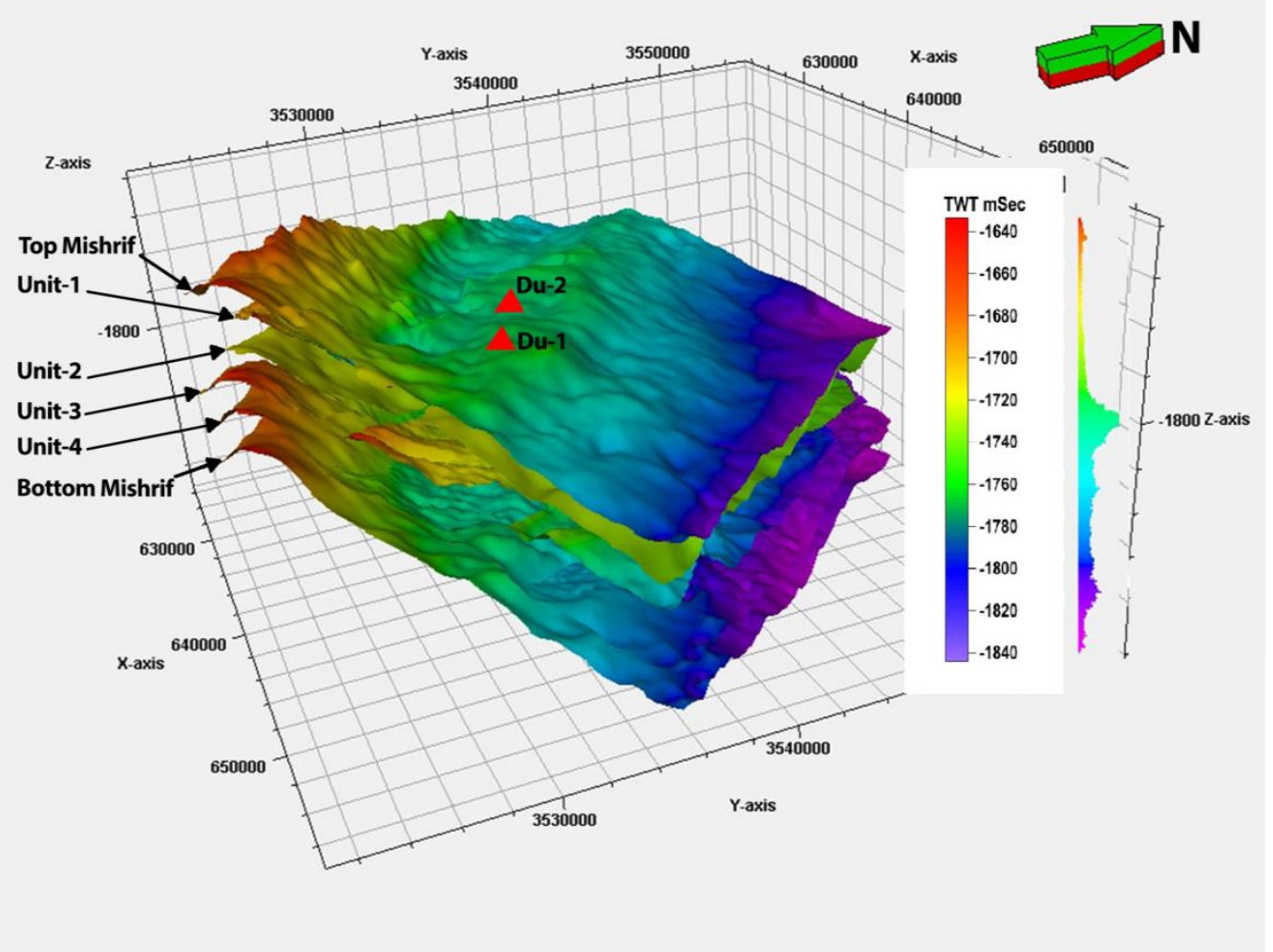

Figure 5- The 3D-seismic reflection horizons model of Mishrif Formation.

The two-way time (TWT) structural maps and 3D-layers model of Mishrif exhibited several seismic structural features, which can be interpreted depending on the integration with available geological information and wells data, as follows.

In general, the Mishrif layers are inclined toward the east and northeast. The west and southwest sides of the map are rising in what could represent a part of a folded structure extending out of the 
study area. The middle part shows a longitudinal wide flat area extended in the NW-SE direction, that is coincided with the Zagros folded trend. It may represent the shelf of a ramped-carbonate platform [8]. It also showed a simple closure (according to the shape of contour lines) in the region of the two wells of Dujaila-1 and 2, which may be related to the randomly distributed isolated reef buildups (Rudist mound) lithofacies on the rim of the carbonate platform [9]. The elevation time in the east and northeast sides is steeply lowering, which may represent a part of the deep basin. The time map of the bottom Mishrif generally showed the same topographic picture of the top Mishrif surface, but the longitudinal flat area in the middle part became narrow with slight reliefs. This may reflect the absence of reef buildups and vertical variations in the lithofacies succession.

\section{Construction of 3Dimensional-Velocity Model}

Building a velocity model on accurate geological and geophysical information is an important step in the depth conversion and seismic interpretation [10]. 3D-velocity model is one of the best techniques, where the use of time depth relation is necessary to convert to depth or thickness of the subsurface layers that are interpreted from seismic reflection images in the time domain. It may also show a real picture of the subsurface setting [11]. A 3D-average velocity model was constructed using Petrel software, depending on the linear equation $\mathrm{V}=\mathrm{V}_{0}+\mathrm{K} * \mathrm{Z}$, where: $\mathrm{V}$ is the average velocity, $\mathrm{V}_{0}$ is the instantaneous velocity, $\mathrm{K}$ is time/ depth gradient, and $\mathrm{Z}$ is the depth. This moder explains the distribution of velocity, in both vertical and horizontal directions, that is calibrated to wells check-shot velocities, as shown in Figure-6.

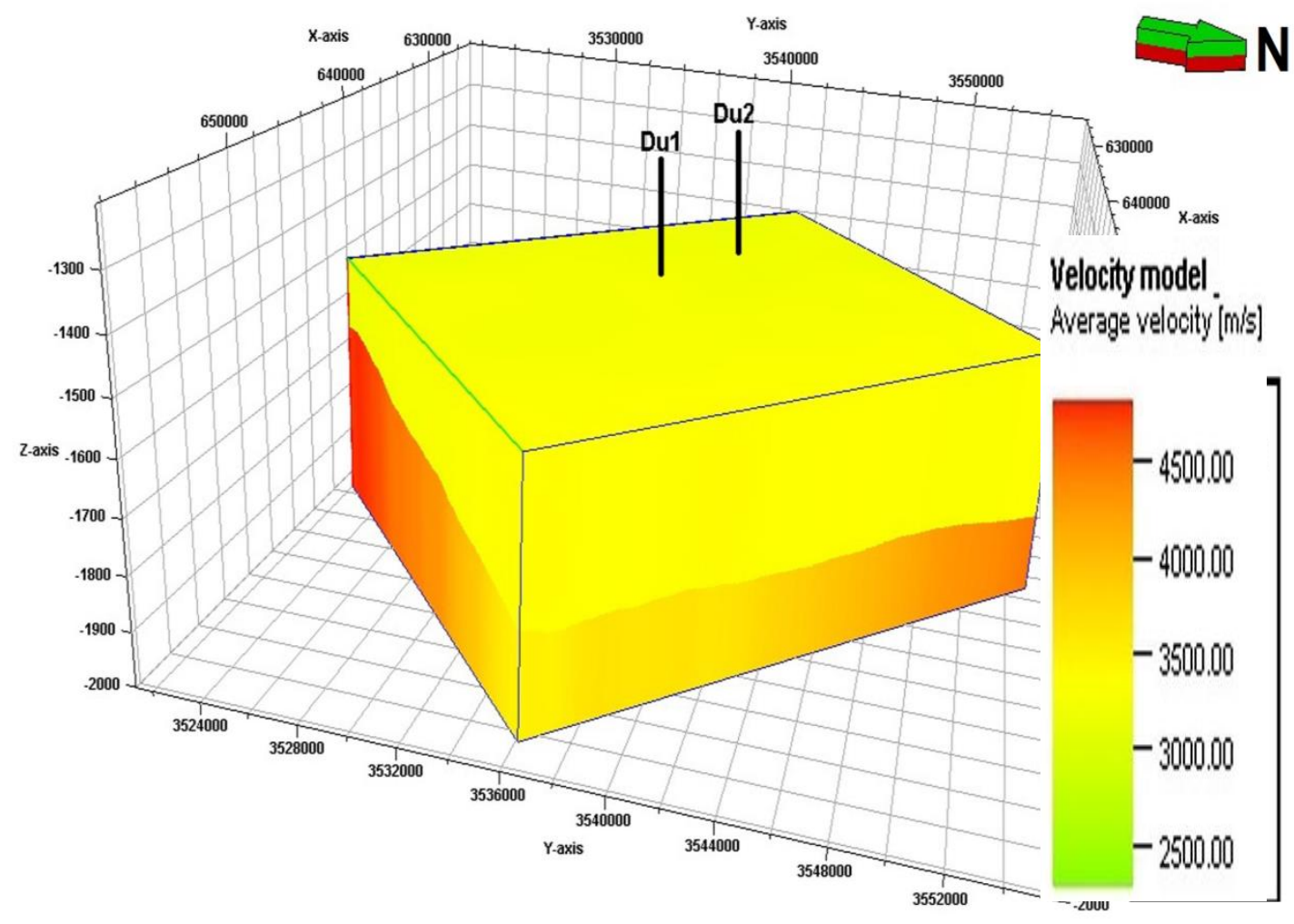

Figure 6- The 3D-velocity model of Mishrif Formation in Dujaila oil field.

\section{Average velocity map}

To study the behavior of the velocity throughout Mishrif Formation in the Dujaila oil field, average velocity maps were drawn for the top and bottom surfaces of the formation from the 3D velocity cube, as illustrated in Figures 7 and 8, respectively. 


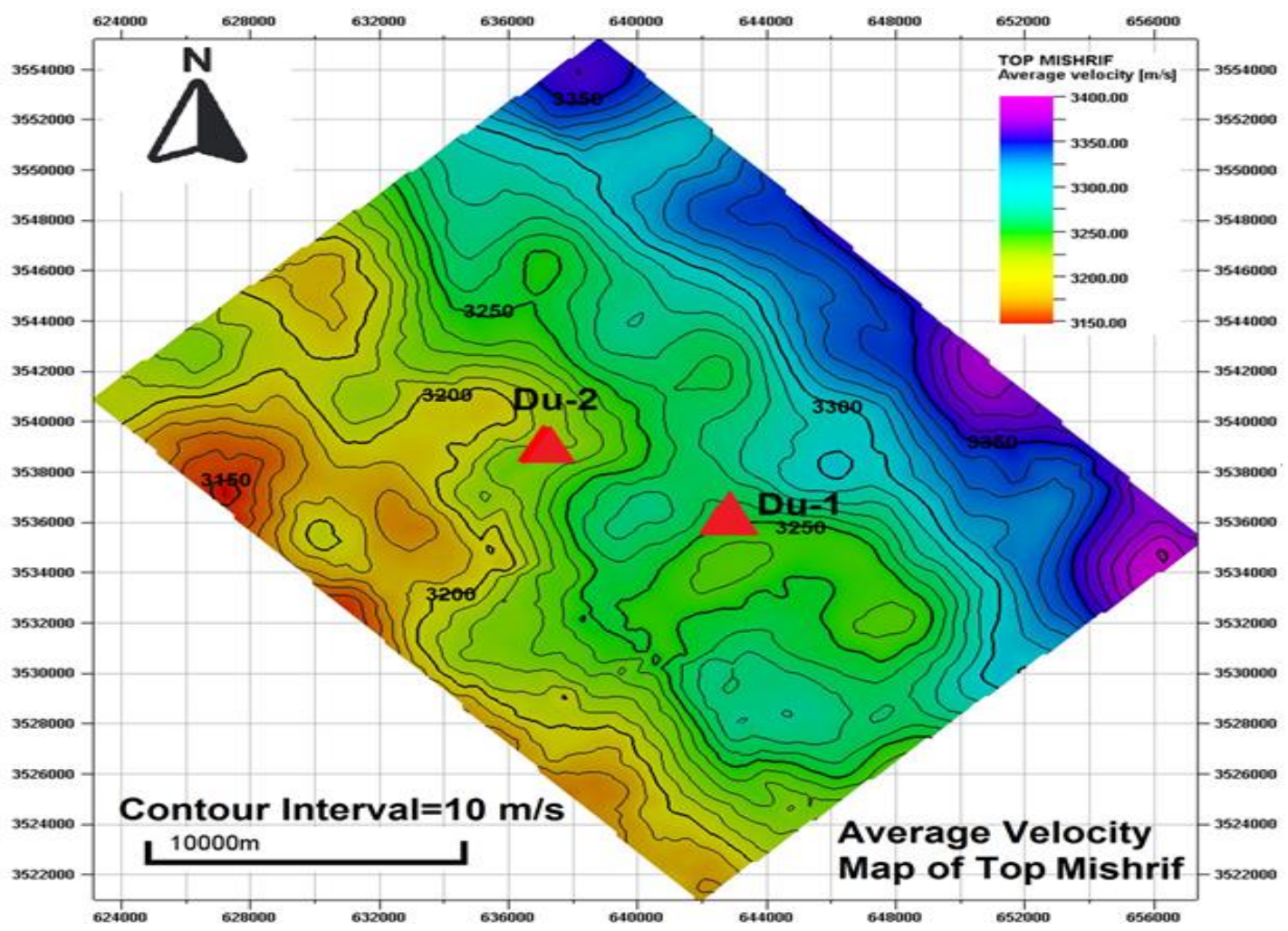

Figure 7- The average velocity map of top Mishrif with contour interval of $10 \mathrm{~m} / \mathrm{s}$.

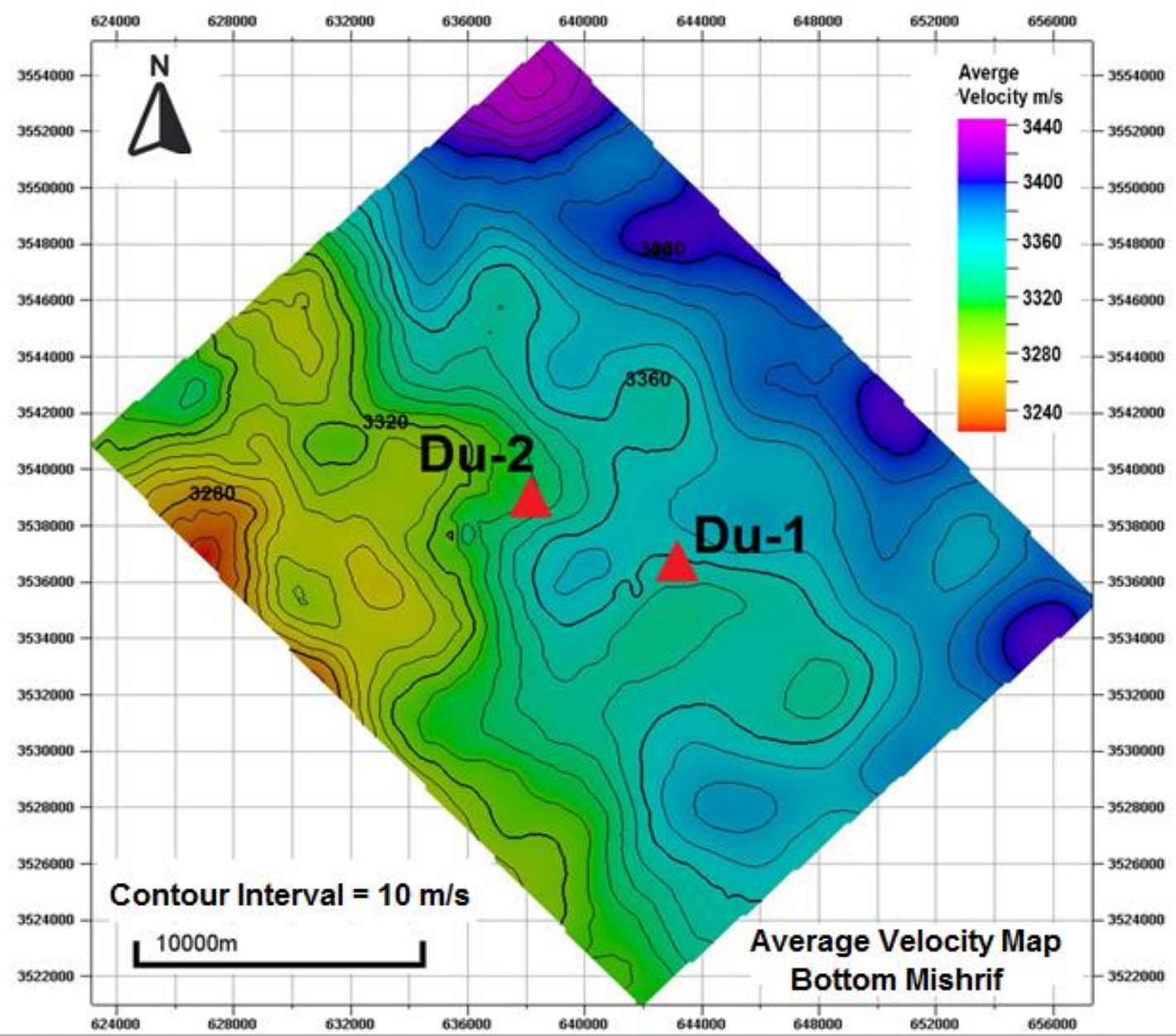

Figure 8- The average velocity map of bottom Mishrif Formation with contour interval of $10 \mathrm{~m} / \mathrm{s}$. 
In general, the two velocity maps demonstrated an increase in the velocity values toward the east and northeast, with a slight gradient of about $250 \mathrm{~m} / \mathrm{s}$ throughout the study area. They also showed that the contour lines have a longitudinal shape that extends in the NW-SE trend. The velocity map of top Mishrif (Figure -7) exhibited velocity anomaly in the region of well Dujaila-1, that is distinguished by a low velocity relative to the velocity values of the surrounding area. This negative anomaly reveals lateral changes in the physical properties of the adjacent lithofacies, so that it is associated with the presence of porous reef buildups and hydrocarbon accumulation in the region of well Dujaila-1 [8]. While the average velocity map of the bottom Mishrif (top Rumaila), as shown in Figure-8, shows an increase in the magnitude of velocity value and the absence of the negative anomaly, especially in the area around well Dujaila-1. It also indicates vertical changes in the lithofacies succession.

\section{Depth Maps of Mishrif Formation}

A depth map is resulted from multiplying the average velocity map with the one-way time map (isochron map). In other words, at each common midpoint (CMP) of the area with the normal incident of seismic rays, a vertical depth value $(\mathrm{Z})$ is computed $(\mathrm{Z}=\mathrm{VT} / 2)$ from the velocity value $(\mathrm{V})$ and the reflected one-way vertical time (T/2) that is known from the two-way time (TWT) at that point [12, 13]. Hence, to obtain depth maps, the picked time data of any reflector is needed to the velocity data. The most accurate velocity to be used in the conversion from time to depth is the average velocity. It represents the actual velocity of formation that is computed directly from well data and can be derived from the 3D velocity model [14]. The structural contour map illustrated the locations of anomalous structural features based on the geometrical shape of contour lines, and it displayed a general picture of the subsurface structural setting of the survey area. The depth map showed approximately what a time map could look like, especially when the vertical and horizontal variations in velocity are small. While, when the velocity variation is large, the two contour maps (time and depth maps) are expected to show some dissimilarity, especially in the size and extent of the anomaly $[15,16]$.

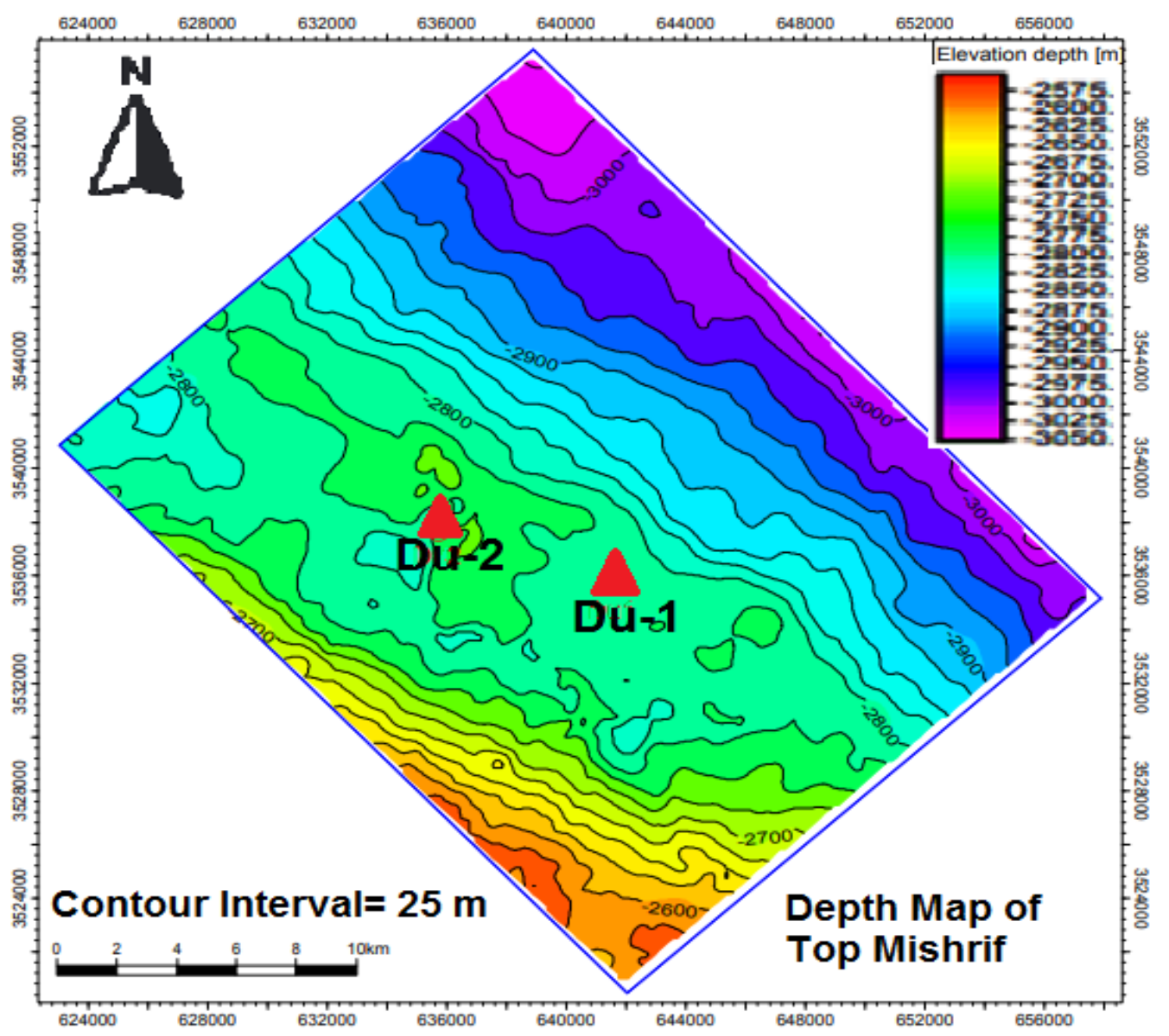

Figure 9- The depth map of top Mishrif Formation with contour interval of $25 \mathrm{~m}$. 


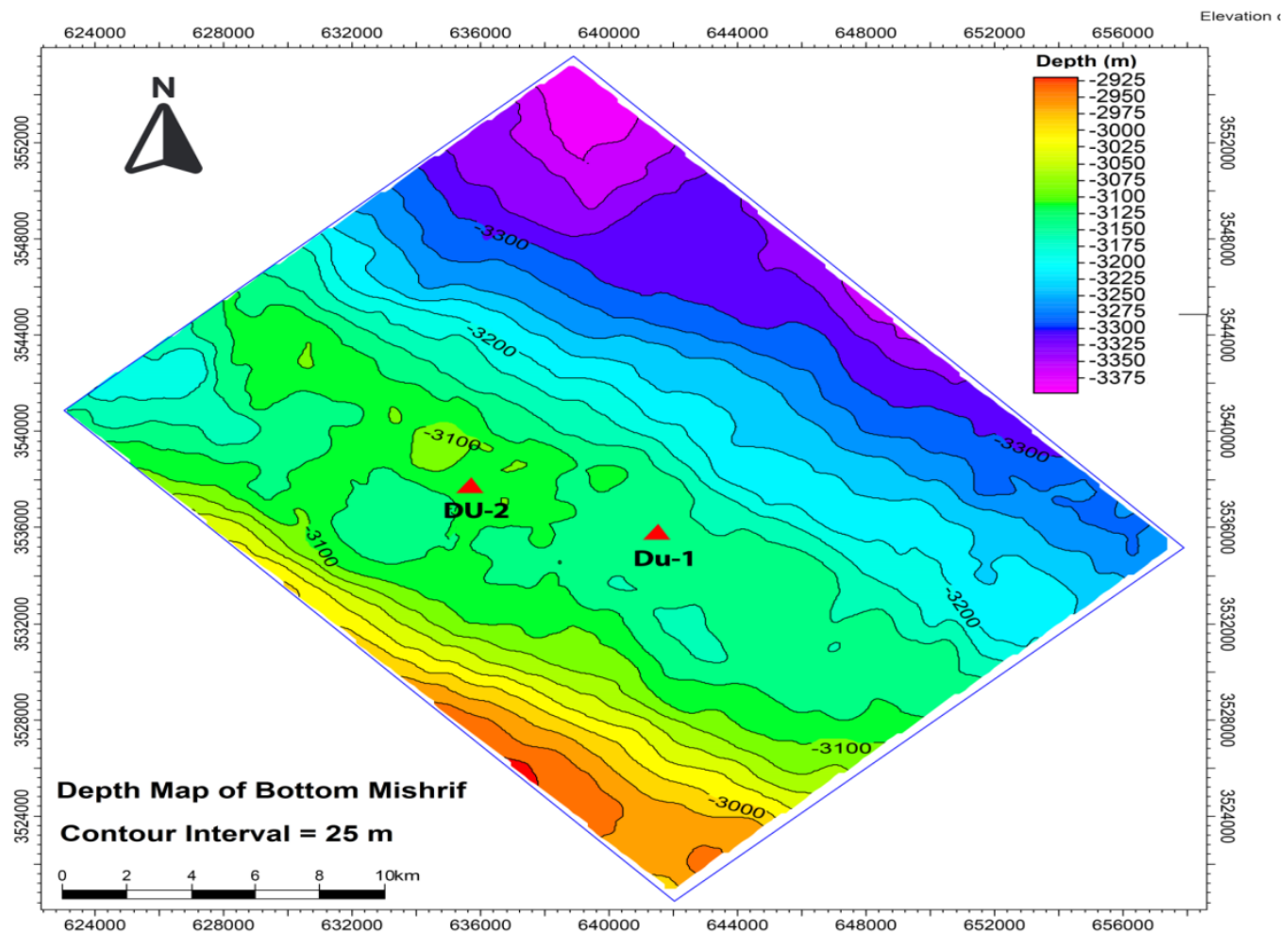

Figure 10- The depth map of bottom Mishrif with contour interval of $25 \mathrm{~m}$.

The two structural depth maps of top and bottom Mishrif, Figures- 9 and 10, showed that the study area is generally a monocline structure dipping toward the east and northeast. They also show that the southwest part is a rising area, which is then lowering toward the middle part of the study area, which is a longitudinal broad flat area extending in the NW-SE trend. It represents a ramped carbonate platform, whereby the two wells are located in the zone of the shelf edge or basin margin. Then, the depth is steeply sloping in the east and southeast parts of the study area, which represent a deep basin. This is compatible with the structural and stratigraphic images of the formation that resulted from the interpretation of the seismic reflection events of the study area, as seen in Figure-11, which represents an arbitrary seismic section that passes through the two wells of Dujaila-1 and 2 with its geologic interpretation.

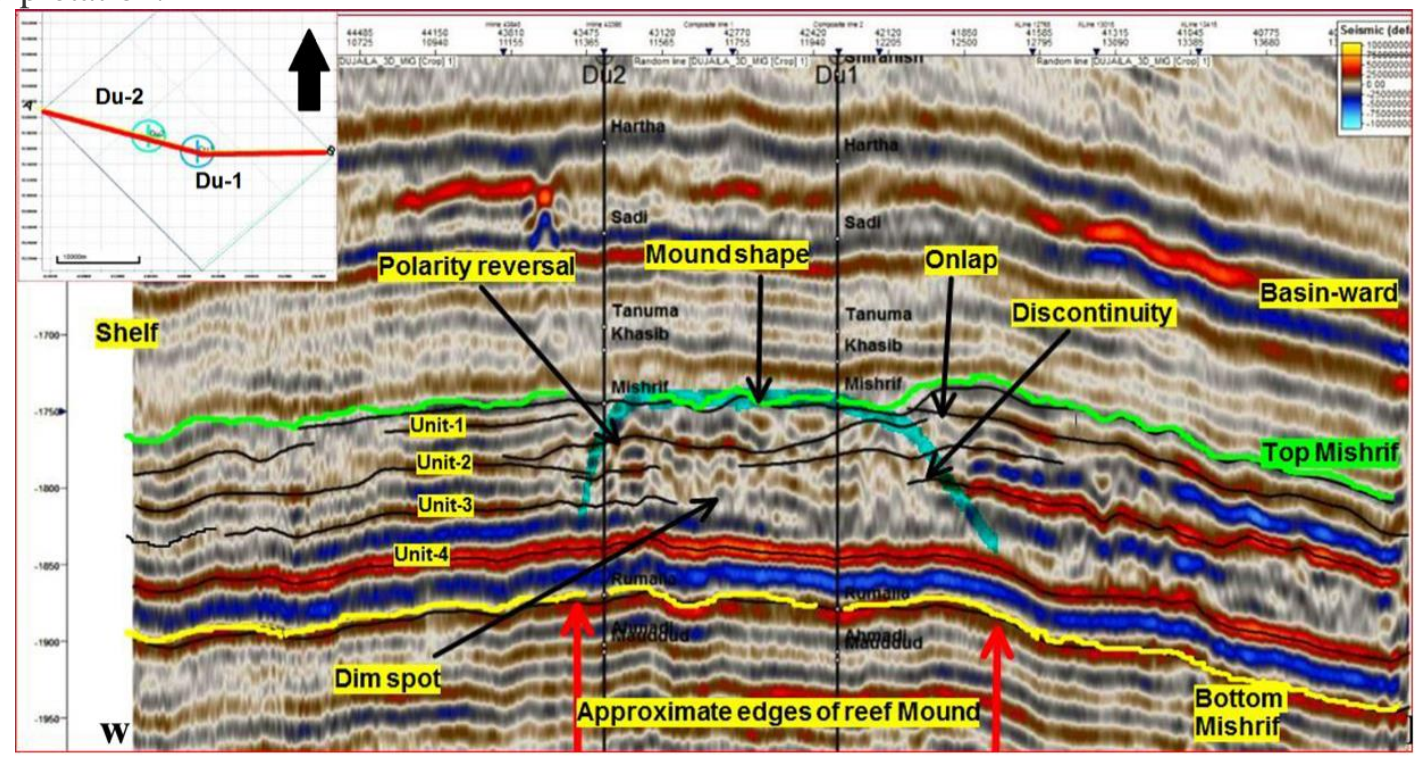

Figure 11- The geological interpretation of the seismic reflection section that passes through the wells of Dujaila-1 and 2. 


\section{Isopach Map of Mishrif Formation}

An isopach map shows the real thickness of a Formation that is created from the integration of seismic and well data. Thickness map is useful in the studying of the depositional environments that are associated with the thickness variations, structural growth of sediments, identification of the sediment source, and zones of lateral changes in the lithofacies [12]. The thickness of the Formation is a final result of the various interactions of the depositional environment conditions that include the local sea level fluctuations, tectonic activity, climate conditions, and the sediment supply [17]. Therefore, the Formation depositional environment can be identified depending on its thickness and configuration shape of the seismic reflection events [18]. An isopach map was obtained by subtracting the top map from the bottom depth map [14], as shown in Figure-12.

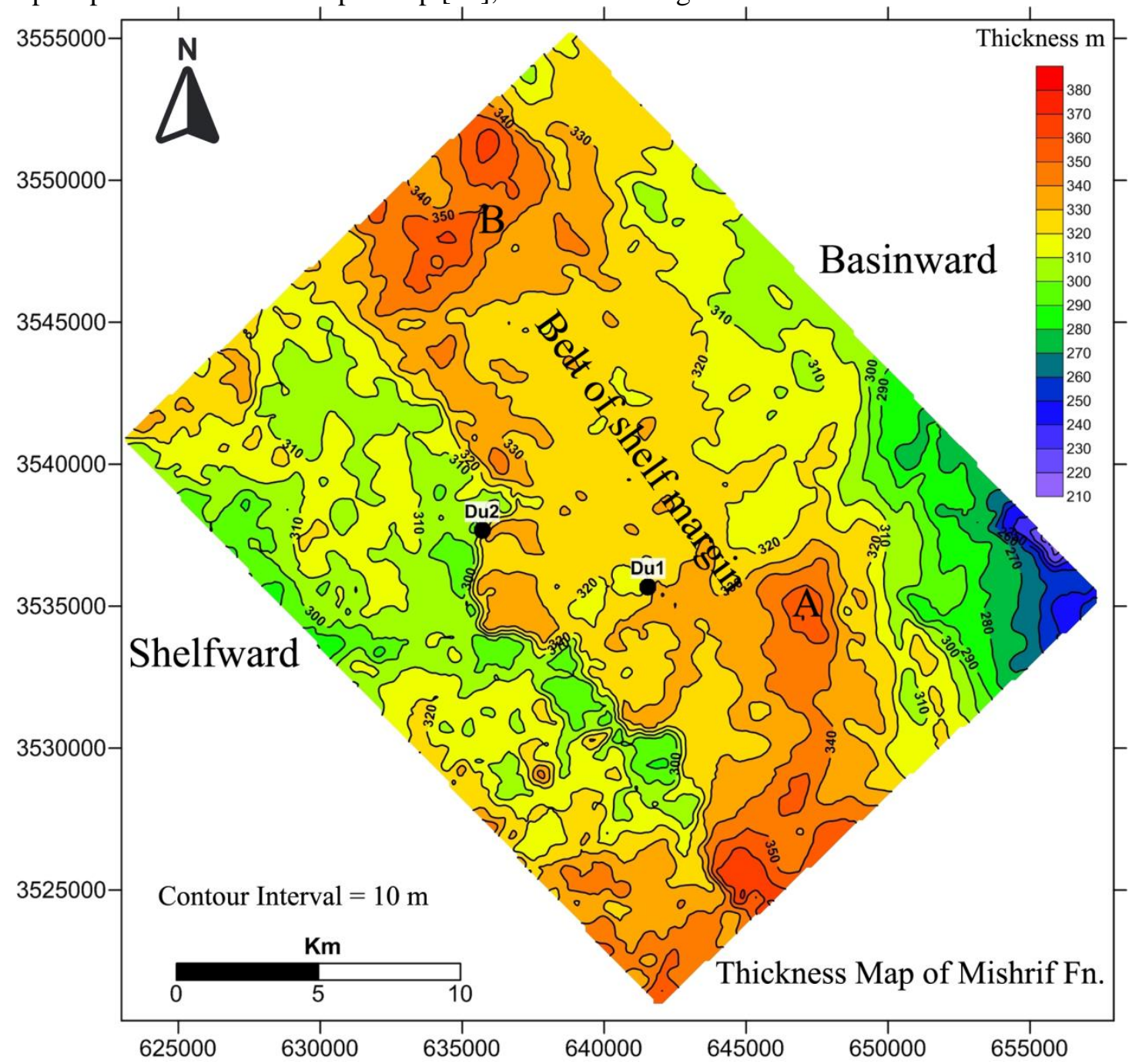

Figure 12- The isopach (thickness) map of Mishrif Formation in Dujaila oil field with contour interval of $10 \mathrm{~m}$. The higher thickness values of the Formation were marked with the letters A and B.

Based on the integration of the 3D seismic data and well information, the isopach map of the study area can be interpreted as follows:

- The thickness of the Formation in the west and northwestern parts of the study area has approximately the same value of about $300 \mathrm{~m}$. The shelf zone is distinct by the relative stability of sea level and climate conditions, which has led approximately to the deposition of equal thickness and homogeneous rocks. Besides, their seismic section exhibited continuous and parallel reflection horizons with high amplitude frequency [18], as seen in Figures- 11 and 12. Thus, this part represents a shelf area of the ramped-carbonate platform of a shallow open marine environment that is associated with a back-reef facies deposit [19].

- The thickness of Mishrif Formation is increasing to more than $350 \mathrm{~m}$ at two separate regions (marked by letters A and B) in the middle part of the map, especially where the well Dujaila-1 is 
located. Furthermore, its seismic section showed discontinuous, mound-shaped, marginal, onlapping reflections, that is compatible with the location that was interpreted as a reef mound grown on the shelf edge, as shown in Figure-11. In addition, the central part appears to be a narrow longitudinal belt extended in the NW-SE direction. It represents a rim of the carbonate platform, or a belt of shelf margin, associated with the random distribution of the rudist reefal mound, which clearly appears in the region A with a high thickness in the vicinity of the productive well Dujail-1, where it is the preferential place for reef growth. This confirms that the distribution and thickness of the rudist buildup are controlled by paleo-high features on the rim belt of the carbonate platform [20].

- In the east and southeast parts of the study area, the thickness is decreasing to less than $250 \mathrm{~m}$, which may represent a deep basin. The open marine environment of the deep basin does not encourage the production of carbonate rocks, which leads to the reduced thickness of carbonate rocks that are dominated by fore-reef lithofacies [17]. Meanwhile, its seismic section exhibited continuous reflection horizons with low amplitude events, which distincts the deep basin environment [18], as noticed in the seismic section in Figure-11. Thus, this part of the study area represents a deep basin of the open marine environment that is associated with the fore-reef facies deposit $[18,17,9]$.

- The productive well, Dujaila-1, was drilled in the region A of the high thickness of a rudist reefal buildup [9]. While the dry well, Dujaila-2, was drilled at an outer side of these regions of high thickness of Rudist mounds, which explains why it is dry.

- The thickness values of the Mishrif Formation that are obtained from the isopach map are closely coincided with the true thickness values of the well data [3], as shown in Tabl-1.

Table 1- The thickness values of Mishrif Formation obtained from the seismic isopach map and well data.

\begin{tabular}{|c|c|c|}
\hline Thickness $(\mathbf{m})$ & Well data (EOC, 2013) & Seismic isopach map data \\
\hline Dujaila-1 & $323.1 \mathrm{~m}$ & $324 \mathrm{~m}$ \\
\hline Dujaila-2 & $309 \mathrm{~m}$ & $310 \mathrm{~m}$ \\
\hline
\end{tabular}

\section{Construction of 3D- depositional model of Mishrif Formation}

Based on the analysis of the seismic isopach map and geologic information of wells data, the diagram of the 3D depositional environment model of Mishrif Formation in the study area was constructed, as shown in Figure-13. It demonstrates that Mishrif formation (Cenomanian-early Turonian) consists of three depositional environments; in the west and northwestern part is a shallow open marine environment of the shelf of the carbonate platform that is associated with back reef lithofacies of a uniform thickness, whereas the middle part represents a shelf margin belt of the shoal environment that is associated with isolated rudist reefal mound lithofacies of higher thickness, and the east and southeastern parts of the study area is a deep basin of the open marine environment associated with the fore reef lithofacies of thin thickness.

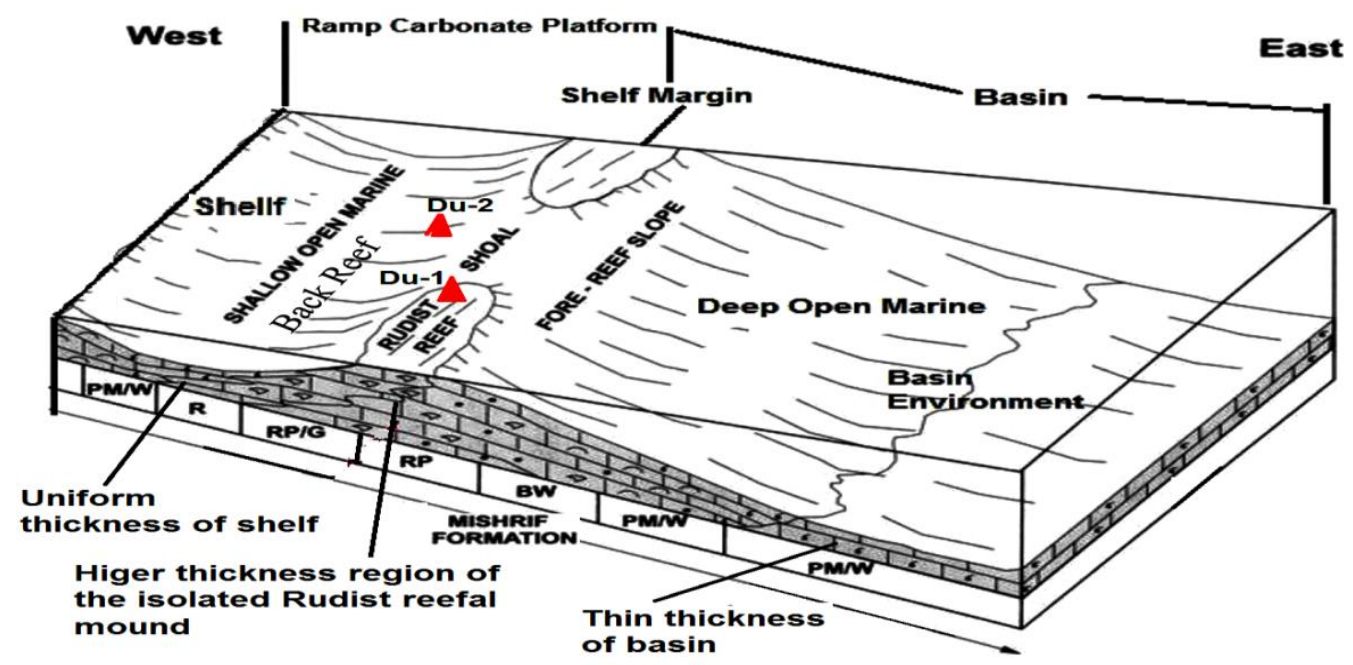

Figure 13- Diagram of the 3D-depositional environments model of Mishrif Formation in Dujaila oil field that is derived from seismic data. 


\section{Instantaneous Seismic frequency attribute}

The seismic attribute technique allows us to increase the ability of geological interpretation of a formation, particularly in the thin-bed reservoir environments [21]. There is an inverse relationship between the thickness of a rock layer and the corresponding peak frequency of its seismic reflection. That is, thinner rock layers are much more apparent at higher frequencies, whereas thicker rock layers are much more apparent at lower frequencies. This can be used to qualitatively identify thinning or thickening of a rock units in different directions [22].

The real 3D model of the instantaneous frequency attribute was generated from 3D-seismic data of Mishrif Formation in the Dujaila field by using the Petrel software, as shown in Figure-14. The frequency model showed that the low-frequency $(15 \mathrm{~Hz})$ is restricted in the area around the productive, well Dujaila-1, which confirmed the presence of porous rudist buildups of high thickness on the shelf margin. In addition, it showed that the western and northwestern parts of the study area have approximately a moderate frequency $(25-35 \mathrm{~Hz})$ of continuous reflection horizons, due to the presence of back reef lithofacies in the shelf of the carbonate platform that were deposited in the shallow open marine environment. Whereas, the east and southeastern parts are dominated by high frequency $(40-50 \mathrm{~Hz})$ reflection events, due to the presence of the tight limestone of the fore reef lithofacies that were deposited in the open marine deep basin environment [23], as shown in Figure 14. As a result, the use of the instantaneous frequency attribute confirmed the ability to predict the depositional environment from the seismic isopach map.

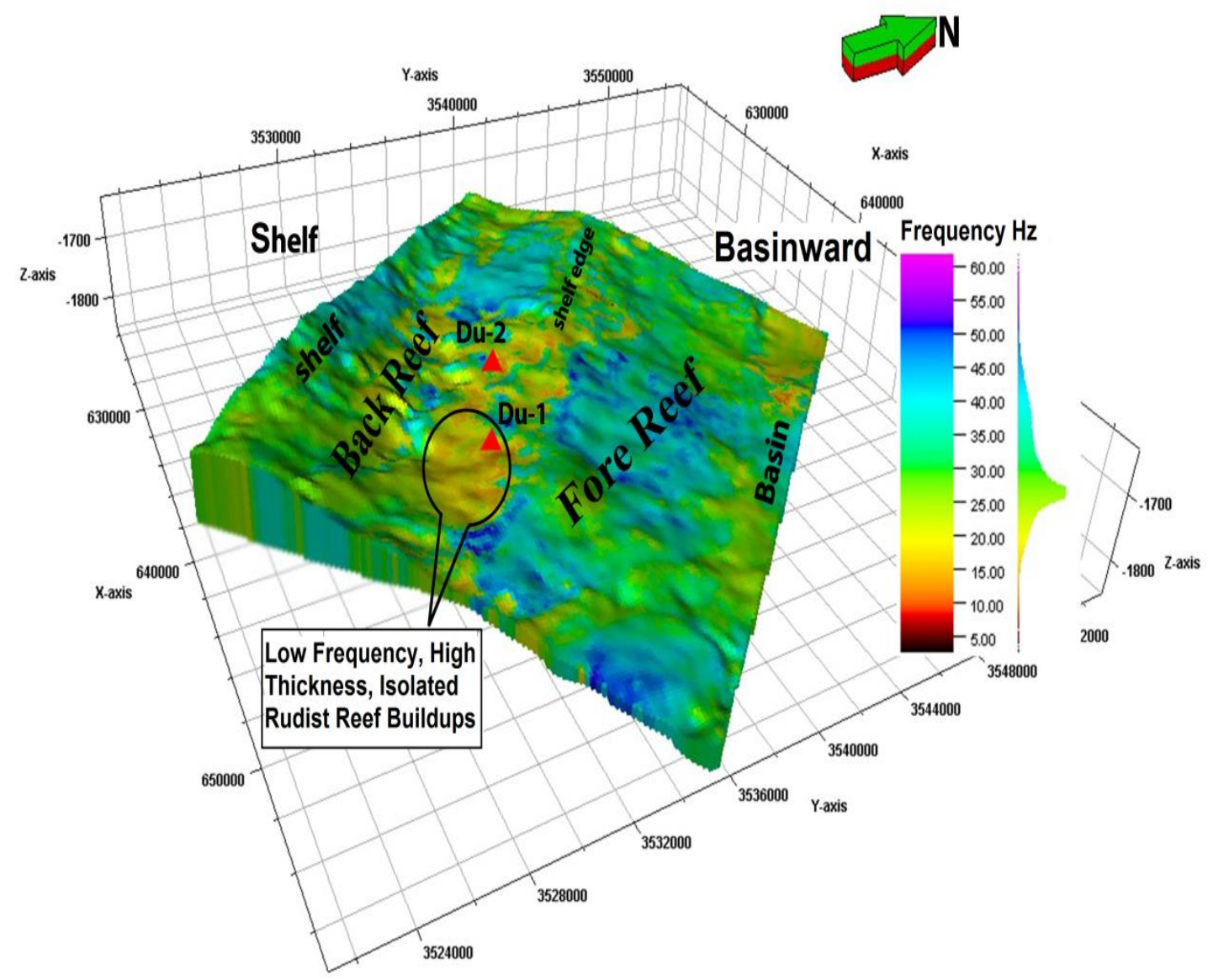

Figure 14- The actual 3D-seismic frequency model with the depositional environments of Mishrif Formation in Dujaila oil field. 


\section{Conclusions}

1. A 3D-depositional environment model of Mishrif Formation was predicted directly from the seismic isopach map to illustrate the general configuration of the depositional basin architecture and horizontal lithofacies environments distribution.

2. The created 3D-lithofacies environment model of Mishrif Formation in Dujaila field demonstrated three essential depositional environments, which were graduated from the back reef of the open marine environment in west and NW to the reef of the shoal environment in the middle, and the fore reef of the deep open marine environment in SE of the field.

3. The Instantaneous frequency attribute supported and confirmed the ability to predict the depositional environment from the seismic isopach map, which in turn showed that the low frequency was restricted to the region of the high thickness of rudist reef buildups (porous reservoir facies) that grow in the shoal environment over the belt of the shelf edge.

\section{Acknowledgement}

I am presenting my thanks to the Interpretation Department / Oil Exploration Company / Iraqi Oil Ministry to support my research by providing me with data, references, and a computer with software. I extend my gratitude to all my professors and geophysical colleagues in the Department of Geology, University of Baghdad, for their scientific efforts in the success of this research.

\section{References}

1. Jallalalhosseini, S.M., Eskandari, S. and Mortezazadeh, E. 2015. The technique of seismic inversion and use of the relation between inversion results and porosity log for predicting porosity of a carbonate reservoir in a south Iranian oil field. Energy Sources, Part A: Recovery, Utilization, and Environmental Effects, 37(3): 265-272.

2. de Buyl, M., Guidish, T. and Bell, F. 1988. Reservoir description from seismic lithologic parameter estimation. Journal of petroleum technology, 40(04): 475-482.

3. OEC (Oil Exploration Company), 2013. Detailed Interpretation of 3D-seismic Reflection Survey for Dujaila Oil Field-A/1/219. Internal report. Iraqi Oil Ministry.

4. OEC (Oil Exploration Company), 2008. Reinterpretation of 2D-seismic data of the Dujaila fieldA/1/91, internal report. Iraqi Oil Ministry.

5. Buday, T., 1980. The regional geology of Iraq: tectonism, magmatism and metamorphism (Vol. 2). State Organization for Minerals, Directorate General for Geological Survey and Mineral Investigations.

6. Fouad, S.F., 2015. Tectonic map of Iraq, scale 1: 1000 000, 2012. Iraqi Bulletin of Geology and Mining, 11(1): 1-7.

7. Eberli, G.P., Masaferro, J.L. and Sarg, J.F. eds., 2004. Seismic imaging of carbonate reservoirs and systems: $A A P G$ Memoir 81(81). AAPG.

8. Sadooni, F.N., 2005. The nature and origin of Upper Cretaceous basin-margin rudist buildups of the Mesopotamian Basin, southern Iraq, with consideration of possible hydrocarbon stratigraphic entrapment. Cretaceous Research, 26(2): 213-224.

9. Aqrawi A. A. M., Goff J. C., Horbury A. D., and Sadooni F. N., 2010, The Petroleum Geology of Iraq, Printed in Great Britain by Cambrian printers, Aberystwyth, 424p.

10. Schultz, P. and Canales, L., 1997. Seismic velocity model building: CE in Dallas, 2 November. The Leading Edge, 16(7): 1063-1064.

11. Kelly, K.R. and Marfurt, K.J. eds., 1990. Numerical modeling of seismic wave propagation (Vol. 13). Society of Exploration Geophysicists.

12. Telford, W.M., Telford, W.M., Geldart, L.P., Sheriff, R.E. and Sheriff, R.E., 1990. Applied geophysics. Cambridge university press.

13. Alsadi, H.N., 2017. Seismic Hydrocarbon Exploration $2 D$ and $3 D$ Techniques, Springer international publishing Switzerland.

14. Brown, A.R., 2011. Interpretation of Three-Dimensional Seismic Data: AAPG Memoir 42, /SEG Investigation in Geophysics, No. 9 (Vol. 42). AAPG.[Book].

15. Sheriff, R.E. and Geldart, L.P., 1995. Exploration seismology. Cambridge university press.

16. Herron, D.A., 2011. First steps in seismic interpretation. Society of Exploration Geophysicists. 
17. Sharland, P.R., Casey, D.M., Davies, R.B., Simmons, M.D. and Sutcliffe, O.E., 2004. Arabian plate sequence stratigraphy-revisions to SP2. GeoArabia, 9(1):199-214.

18. Fontaine, J.M., Cussey, R., Lacaze, J., Lanaud, R. and Yapaudjian, L., 1987. Seismic interpretation of carbonate depositional environments. AAPG bulletin, 71(3): .281-297.

19. Burgess, P.M., Winefield, P., Minzoni, M. and Elders, C., 2013. Methods for identification of isolated carbonate buildups from seismic reflection data Identification of Isolated Carbonate Buildups from Seismic Reflection Data. AAPG bulletin, 97(7): 1071-1098.

20. Du, Y., Chen, J., Cui, Y., Xin, J., Wang, J., Li, Y. Z., \& Fu, X., 2016. Genetic mechanism and development of the unsteady Sarvak play of the Azadegan oil field, southwest of Iran. Petroleum Science, 13(1): 34-51.

21. Barnes, A.E. ed., 2016. Handbook of poststack seismic attributes. Society of Exploration Geophysicists.

22. Koson, S., Chenrai, P. and Choowong, M., 2014. Seismic attributes and their applications in seismic geomorphology. Bulletin of Earth Sciences of Thailand, 6(1): 1-9.

23. Chopra, S. and Marfurt, K.J., 2007. Seismic attributes for prospect identification and reservoir characterization. Society of Exploration Geophysicists and European Association of Geoscientists and Engineers. 